\title{
The Restoration of Fiscal Stability. A Public Choice Approach on the Problem of Public Debt
}

\author{
Panagiotis Evangelopoulos \\ Department of Economics, University of Peloponnese, Tripolis, Greece \\ Email:panevans@uop.gr
}

How to cite this paper: Evangelopoulos, P. (2018) The Restoration of Fiscal Stability. A Public Choice Approach on the Problem of Public Debt. Theoretical Economics Letters, 8, 147-158.

https://doi.org/10.4236/tel.2018.82010

Received: November 13, 2017

Accepted: February 3, 2018

Published: February 6, 2018

Copyright $\odot 2018$ by author and Scientific Research Publishing Inc. This work is licensed under the Creative Commons Attribution International License (CC BY 4.0).

http://creativecommons.org/licenses/by/4.0/

\begin{abstract}
In contemporary democracy fiscal policy is not employed for the fiscal control of necessary state activities but for generation of deficits which causes the state to feed on itself, expands enormously in the service of special interests and is contrary to the public's interest in fiscal stability and discipline. Starting from the origin of and the reason for, the classical liberal state, I undertake an analysis of the historical theoretical background of public choice. The development and application of public choice analysis can work towards restoring fiscal stability, especially after the outbreak of the global financial crisis that generated the enormous increases in the public deficit and debt in the developed democracies.
\end{abstract}

\section{Keywords}

Fiscal Stability, Public Choice, Classical Liberal State, Democracy

\section{The Classical Liberal State}

The state is the basic institution of organization in contemporary societies. Historically, in the modern age, from the need for a state and for strong centralized power, which was the dominant political demand of the societies of the $16^{\text {th }}$ and $17^{\text {th }}$ centuries, we have moved on to the societies of the $20^{\text {th }}$ century, where the state has acquired institutional solidity, expanding functionally into almost all spheres of action in economic and social life. In the $20^{\text {th }}$ century, apart from its central political role-which inherited from the $19^{\text {th }}$ century-the state embarked on a course of continual expansion, implementing actively interventionist economic and social policies. 
There was a parallel shift in the theoretical interpretation of the state. Thus from the all-powerful tightly-consolidated state sought by Machiavelli in the person of The Prince ${ }^{1}$ [1], and also by Thomas Hobbes ${ }^{2}$ in Leviathan [2], "that there might be order in the jungle of human affairs", we proceed to the classical liberal state of Locke ${ }^{3}$ [3], whose purpose was to protect, with a minimum of intervention, the natural rights of individual freedom and property. The appearance of Adam Smith ${ }^{4}$ [4] and his work at the end of the 18th century served to consummate the classical liberal system of John Locke [3], forging an indissoluble link between the concepts of economic and political freedom. This is the type of state bequeathed to the 19th century by the European Enlightenment and the philosophers of Natural Rights: a state with a central political role but with minimum economic and social intervention, a state that was dubbed by its anti-liberal opponents "the night watchman state".

The most powerful critique of the classical liberal state was articulated by Karl $\operatorname{Marx}^{5}$ [5], who laid the foundations for his critique during the 19th century, when the classical liberal state was at its zenith. Marx's scientific socialism presumed the formation of a state controlled and administered by the Communist Party in the name of the proletariat ${ }^{6}[6]$. Through the state the proletariat would control the means of production and make decisions on the just distribution of wealth. But as we know these theories did not prosper and the planned societies ${ }^{1}$ The most prevalent view is that Machiavelli's "Prince" is the political theory of comprehensive justification of all possible means, fair and foul, that might be employed to secure his absolute rule. But for those who study it attentively "The Prince" comprises a political handbook for the creation of a powerful, united, monarchic state at a time when Italy was fragmented and in thrall to foreign powers. Niccolo Machiavelli, “The Prince”, Bedford/St. Martin's, 2004.

${ }^{2}$ For Hobbes, state power had to be absolute and omnipotent, precisely like the monster described in the Bible. It was from this that Hobbes gave the book its title. Thomas Hobbes, "Leviathan", Cambridge University Press, 1996.

${ }^{3}$ John Locke established the hard core of the classical liberal state: exclusive responsibility for protection of individual freedom, which is inextricably associated with private property. John Locke, with his work, founded the political liberalism. There is further analysis of this in the book by Ellen Frankel Paul, "Property Rights and Eminent Domain”, Transaction Inc., 1987 [45] and naturally in the primary source, John Locke, “Two Treatises of Government”, Cambridge University Press, 1988. ${ }^{4}$ With the work of Adam Smith economic liberalism is consummated as a system for organizing society. Nevertheless the 20th century was to see a merging of economic liberalism (Adam Smith) and political liberalism (John Locke) with the contribution of the New Austrian Economists and in particular the work and thought of Ludwig von Mises and Friedrich Hayek along with the contribution of the economists of the Chicago School, notably Milton Friedman, of the Public Choice School, notably James Buchanan, of the Property Rights School, notably Ronald Coase. See Ludwig von Mises "Human Action: A Treatise on Economics" Libertry Fund 2010 [47] and "Liberalism", Liberty Fund, 2005 [46]. Friedrich Hayek "Law, Legislation and Liberty”, Routledge \& Kegan Paul, 1976 [48] and "Studies in Philosophy, Politics and Economics", Routledge \& Kegan Paul, 1978 [49]. Milton Friedman "Capitalism and Freedom", The University of Chicago Press, 1982 [50]. James M. Buchanan "The Logical Foundations of Constitutional Liberty, Liberty Fund, 1999, [51] and "Collected Works of James M. Buchanan”, Liberty Fund, 2004 [52]. Ronald Coase “The Firm, the Market, and the Law", The University of Chicago Press, 1988 [53].

${ }^{5}$ Karl Marx, “Capital”, International Publishers, 1967.

${ }^{6}$ Karl Marx and Friedrich Engels, “The Manifesto of the Communist Party" In Readings in Economics pp. 395-404 (P.A.Samuelson, R.L.Bishop, J.R.Coleman eds., McGraw-Hill Book Company 1952). 
centrally organized $^{7}$ [7] [8] by a socialist state failed ${ }^{8}$ [9]-[19].

The most important development to be noted in the vicissitudes of the 19th century classical liberal state was its gradual transformation in the course of the 20 th century ${ }^{9}[20]$ and its progressive elaboration into a spectrum of multi-faceted economic and social activities funded through the continuously accumulated public deficits establishing the enormous levels of public debt that above all characterise the developed democracies of the $21^{\text {st }}$ century ${ }^{10}$ [21]. At the same time the expansion of state activities in contemporary democracies was supported by the restriction of decision making to within the mechanism of the market, accompanied by involvement of the state in the production and provision of a wide range of public goods and services ${ }^{11}$ [22].

James Buchanan and the Public Choice School ${ }^{12}$ [23] came into conflict with the phenomenon of the overextended role of the state in present-day liberal democracies. James Buchanan deplored the permanent situation of deficit into which contemporary democracies had been plunged; censuring John Maynard Keynes $^{13}$ [24] for having through his work ${ }^{14}$ [25] prepared the political and economic ground for liberal democracy's being in its present situation ${ }^{15}$ [26].

My endeavour will accordingly be to demonstrate that fiscal policy in con${ }^{7}$ James M. Buchanan, (2005, p. 20), writes "This is a form of socialism that is now dead and buried, both in ideas and in practice, having been "done in" during the last decades of the twentieth century."...He stigmatizes $(2005$, p. 22$)$ "(t)he advocates of centrally managed economies... (who)... moved with surprising alacrity to align themselves with the welfare state: social democrats." Janos Kornai (1993, p. 48) also, very characteristically, writes on the subject of the alternative decentralized market socialism that was always more attractive to modern "progressive" Western economists: "thousands of highly intelligent, well-intentioned people in all the countries that experimented with market socialism were unable to hammer out and consistently implement a contract that was guaranteed to operate efficiently".

${ }^{8}$ Hayek $(1935,1940,1988)$ and Mises $(1920,1922)$ had analyzed the failures of socialism well before its collapse. See also Kornai (1959, 1971, 1992, 1993), Boettke (2001), Prychitko (2002), Evangelopoulos $(2009, a)$.

${ }^{9}$ Douglass North (1981, p. 188) writes concerning the transformation of the classical liberal state "The story of this chapter (14) is how the framers of the Constitution (USA) attempted to control the state and how ultimately those controls broke down... the Great Depression was merely an episode that was the immediate vehicle for the acceleration of this transformation. The economists' and the economic historians' failure to analyze structural change has led them to misread the economic history of the twentieth century."

${ }^{10}$ In his research, David B. Smith (2006) concludes that the state cannot any longer fund itself.

${ }^{11} \mathrm{~A}$ critical analysis of the ever greater involvement of the state in the production of public goods is that of James M. Buchanan and Milton Z. Kafoglis, "A Note on Public Choice Supply”, The American Economic Review, Vol. 53, No. 3 (Jun., 1963), 403-414.

${ }^{12}$ Essentially the eminent proponents of the Public Choice School were James Buchanan and Gordon Tullock who jointly authored the key book of this school of economic thought "The Calculus of Consent. Logical Foundations of Constitutional Democracy", Ann Arbor, The University of Michigan, 1962.

${ }^{13}$ James M. Buchanan and Richard E. Wagner, "Democracy in Deficit: the Political Legacy of Lord Keynes", Academic Press, New York, 1977.

${ }^{14}$ As formulated in the book of John Maynard Keynes, "The General Theory of Employment, Interest and Money", Macmillan, 1973.

${ }^{15}$ James M. Buchanan, Richard E. Wagner and others issued their position papers (from a conference which took place in March 1976) in their book, "Fiscal Responsibility in Constitutional Democracy", Martinus Nijhoff, Leiden, 1978. The book contains extensive discussion of democratic means for establishing fiscal equilibrium. 
temporary democracy is utilized not for state fiscal control of necessary productive activities but to generate deficits which cause it to feed on itself, inflating it enormously to serve special interests ${ }^{16}$ [27] contrary to the public's interest in fiscal equilibrium and discipline.

In our day this phenomenon is more than obvious and more than hazardous. In addition to the traditionally high demand for public deficits from political pressure groups that undermines the creation of wealth and redistributes income to unproductive activities ${ }^{17}$ [20], after the outbreak of global financial crisis in 2008, amid the re-emergence of an old-fashioned expansionist

Keynesianism ${ }^{18}$ as a macroeconomic policy to offset the insolvency of big financial corporations, the developed countries in particular (USA, UK ${ }^{19}[28]$ and the EU nations) dramatically increased their fiscal deficits and inflated their accumulated public debt to huge levels. The consequences for fiscal stability could not be worse. This was, after all, an economic policy triggered by the emergency spending bill of the Bush administration and formalized by the election of President Obama with his devoted political support for a giant program of economic stimulus.

An economic policy that propels the economic system straight from global financial crisis to global sovereign debt crisis $^{20}$ [29]. A procedure that introduces unprecedentedly increased systemic risk into the global economy, unavoidably weakening the last resort ${ }^{21}$ [30] role of the state. It is evidently time for restoration of fiscal stability on the basis of an economic policy oriented to the prin-

${ }^{16}$ James M. Buchanan (1993, p. 1), "Political players who might seek to further some conception of an all encompassing general, or public, interest cannot survive. They tend to be eliminated from the political game in the evolution-like selection process".

${ }^{17}$ Douglass North $(1981$, p. 185$)$ gives an in-depth analysis of the $20^{\text {th }}$ century historical phenomenon of increased control of the economy by the state and political pressure groups. "The pluralist control of the state which emerged from the struggle of workers, farmers, and business groups has produced the disintegration of the earlier structure of property rights and replaced it with a struggle in the political arena to redistribute income and wealth at the expense of the efficiency potential of the Second Economic Revolution.”

${ }^{18}$ Against this trend, which was made fashionable with public opinion by the mainstream press, stands the declaration of the economists under the auspices of the Cato Institute (2009): "Notwithstanding reports that all economists are now Keynesians and that we all support a big increase in the burden of government, we the undersigned do not believe that more government spending is a way to improve economic performance. More government spending by Hoover and Roosevelt did not pull the United States economy out of the Great Depression in the 1930s. More government spending did not solve Japan's 'lost decade' in the 1990s. As such, it is a triumph of hope over experience to believe that more government spending will help the U.S. today. To improve the economy, policymakers should focus on reforms that remove impediments to work, saving, investment and production. Lower tax rates and a reduction in the burden of government are the best ways of using fiscal policy to boost growth."

${ }^{19}$ In his article David B. Smith (2009, p. 41) writes emphatically "Whatever the precise measure employed, it is clear that the 22nd April Budget revealed one of the worst looming fiscal crises in Britain's peacetime economic history".

${ }^{20}$ Evangelopoulos (2009b, p. 81), “The greatest danger is that of the state and politicians exceeding all previous excesses of intervention and requiring of the economic system something that it cannot give."

${ }^{21}$ Evangelopoulos (2007) explains the failure of the state in the light of the theories that have been developed in the post-World War II era. 
ciples $^{22}$ [27] and tools of public choice ${ }^{23}$ [31], a policy-within a democratic framework-of constitutional control both of the public deficit and of debt, along with decisive reduction in the size of government.

\section{Democracy and Fiscal Control}

After the Second World War the exercise of fiscal policy was one of the main methods, perhaps the main method, for implementing policies of state intervention. Its objective was to achieve economic stabilization in the short term and redistribution of income in the long term. But the chief instrument for achieving these goals was the fiscal deficit, manipulation of the size and structure of which clearly presupposed a foundation of strong financial support. It was in this way that we ended up de facto in economies which not only tolerated deficits but actively aspired to them for the purpose of making fiscal policy more effective. On these assumptions fiscal control was losing its traditional rationale and was being displaced by policies of expansion.

Notwithstanding their narrowly economic character, these developments nevertheless had immediate and drastic consequences for contemporary democracy. Before we embark upon this subject, which will be our main area of concern, let us pause for a moment on the question of the public deficit. We will concentrate in particular on the USA, whose economic history provides the best possible illustration of the dramatic change in the mode of treatment of the public deficit. Before the 1930s the rule was for fiscal surpluses to be generated in economic boom periods and rising phases of the economic cycle. The fiscal surpluses that were created in the periods of prosperity easily covered the federal deficit and paid off the federal debt generated in times of war and economic recession.

On the basis of this practice a strict regime of fiscal control grew up whereby in years of recession the fiscal deficit that was generated was covered by preceding surpluses which, when they were not adequate in cases of severe recession or long-term or large-scale warfare, had to be restored out of the surplus from the first subsequent favourable years. This long-term strategy of restoration of the deficit successfully supported the economy through depression or war years while preserving the principle of fiscal control in the exercise of governmental policy.

This enabled the state to deal more painlessly with crises, making available previously accumulated surpluses as emergency gold reserves. The contemporary state, by contrast, bloated and weighed down with high levels of public debt and fiscal deficit, is chronically crisis-ridden. Given the great inertia and inflex${ }^{22}$ James M. Buchanan (1993, p. 6), "Public choice theory models the behavior of those politicians who survive and prosper; public choice theory does not induce those politicians who might seek to do otherwise to behave sinfully or selfishly".

${ }^{23}$ In their vital new research Rowley and Smith (2009) apply to the current financial mess the methodology and the policy making of the public choice approach. They develop an analytical framework of applications of public choice theory to the major problems caused by the global financial 
ibility with which it is afflicted it soon shows symptoms of low productivity, increasing unemployment and disinvestment. The situation is aggravated by the absence of suitable gold reserves and other mechanisms that would enable to it to ride out the economic recession and emerge from stagnation. Implementation, therefore, of this rule of dynamic fiscal control to counteract the detrimental effects of economic recession using reserves saved from periods of economic upturn undoubtedly had beneficial consequences. Above all it approached fiscal policy in a rational manner, firstly utilizing it as a means to achieve stable and balanced financing of basic functions of the state; secondly utilizing it as a means to avoid unexpected adverse developments in the economic cycle.

After the 1930s, the decade of massive economic crisis where very large deficits were accumulated, we never again returned to surplus, even after the Second World War, when the global economy experienced growth and prosperity. It was indeed considered that this long-term growth and consolidation of the prosperity of the Western economies in the 1950s and 60s was precisely the achievement, indeed the crowning glory, of the big-budget economies and unrestrained public deficits. This took place under the influence of the Keynesian revolt against the classical liberal tradition of fiscal control and as part of its institution as the post-war orthodoxy in macro-economic policy-making and fiscal management. The ultimate gain from this

Keynesian new orthodoxy ${ }^{24}$ [32] [33] [34] [35] was a deficit in democracy and a disdain for fiscal control, characteristics ${ }^{25}$ [36] whose consequences for management of the economies of modern democracies were to become evident, and did become evident, in the economic morass of stagflation ${ }^{26}$ [31].

Fiscal deficits have therefore greatly reduced the significance of budgetary restraint, whether by governments or by individuals, breaching the continuity that should exist between the microeconomic and macroeconomic levels and between consumption and total levels of production. And this, in turn, in an inexorable chain-reaction, has meant determination of fiscal policy purely at the

${ }^{24}$ This new Keynesian orthodoxy of high progressive taxation and of high levels of public expenditure and deficits is codified in the work of the radical Keynesians, the key exponents in the USA being John Kenneth Galbraith and in the United Kingdom Joan Robinson. John Kenneth Galbraith, "Economics and the Public Purpose", Houghton Mifflin Co., 1973, [54]. "Keynes' General Theory. Reports of Three Decades”, Robert Lekachman (ed), St. Martin’s Press-MacMillan \& Co. Ltd., 1964. Victoria Chick, "Macroeconomics After Keynes", Philip Allan Publishers, 1983. John Hicks, "The Crisis in Keynesian Economics", Basil Blackwell, 1974. Joan Robinson, "Contributions to Modern Economics", Basil Blackwell, 1978.

${ }^{25}$ "Fiscal records for the sixteen years after 1961 tell their own story. Between 1961 and 1976 there was only one year of fiscal surplus for the federal government. Fifteen years of deficits accumulated to the tune of approximately $\$ 240$ billion. The accumulated deficit for 1961-68 was $\$ 60$ billion. For the 1970-74 period it was $\$ 67$ billion. For $1975-76$ it was over $\$ 110$ billion.” James M. Buchanan, "Economics. Between Predictive Science and Moral Philosophy", Texas A\&M University Press, 1987 , p. 389. We observe this growing level of deficit over ever briefer intervals as a basic characteristic of the fiscal derailment.

${ }^{26}$ As the post World War II Keynesian deficits caused the stagflation of '70s so we may encounter the same problem in worse conditions today. David B. Smith (2009, p. 44) explains “Britain's current profligate fiscal policies are more likely to represent a progression to the more advanced and deadly stage of the disease-i.e. 1970s- style stagflation-than a cure." 
level of politics ${ }^{27}$ [37], with governments using fiscal deficits to secure easy re-election, along with continual expansion of governmental intervention and the role of the state in the economy, producing an ever greater number of public goods and services and making them available, inflating deficits in every possible way.

While fiscal control in the classical liberal tradition is subject to the salutary influence of economic science, with the state budget acting as a mechanism for placing financial restraints on the government, fiscal deficit policies in the Keynesian tradition assume an altogether different function of politically pre-empting and funding the vaguely defined needs of the electoral body. The result is that there are no restraints on the utilization of fiscal deficits, which are in the hands of politicians, and no ceilings to act as an upper limit on uncontrolled increases ${ }^{28}[31]$.

This concentration of precious public resources in the hands of politicians makes them a point of reference in the system for the shaping of public choice. Individuals form coalitions, creating-and indeed themselves becoming-pressure groups $s^{29}$ [36] in the service of special interests whose aim is to persuade politicians to shape public choice in accordance with their own particular sets of priorities. Politicians thus take on the technical role of being brokers of the democratic political system, assembling majorities of individuals to legitimate and impose on all of society the task of funding such public goods as are of maximum advantage to powerful pressure groups. The outcome, therefore, of the Keynesian evaluative fiscal tradition of public deficits is the manipulation of public choice in the most inappropriate manne ${ }^{30}$ [36] with the most improper consequences $^{31}$ [36] from the viewpoint of the public interest ${ }^{32}$ [37] [38] [39].

\footnotetext{
${ }^{27}$ Steve Pejovich (1997, p. 290) "A political entrepreneur finds thus in general that offering 'new programs' or 'variations on existing themes' assures a higher survival value in the political market. A recent article in The Banker noted with interest that in the budget debates proceeding in the British Parliament over ten years not a single MP ever proposed a single time to cut expenditures."

${ }^{28}$ Keynesian expansionist policies are followed today by Obama but David B. Smith warns that "the massive increase in the government spending ratio since 1936 suggests that Keynes would not be advocating the same medicine today, because of the likelihood of a fatal overdose." (Smith, D., 2009, p. 44).

${ }^{29} \mathrm{~A}$ more detailed analysis in Chapter 14: "An Economic Theory of Clubs", in the book by James M. Buchanan, "Economics. Between Predictive Science and Moral Philosophy", Texas A\&M University Press, 1987.

30"In an democratic society operating on the Keynesian economic model there are no safeguards against creation of fiscal deficits, as it has become possible to spend without taxing." p. 398 op. cit., Buchanan (1987).

${ }^{31}$ "If the basic decisions on public expenditure and taxes are left to politicians, the economist who recognizes the biases of the political process will reconsider the all-too-easily accepted nostrums of Keynesian policies. The fiscal policy which is 'ideal' for an 'ideal' world is not the best for a world of practical politics." (p. 402, op. cit., Buchanan [1987]).

${ }^{32}$ Steve Pejovich (1997, p. 284), "The welfare losses are actually substantially raised by the 'rent seeking behavior' of potential beneficiaries. The evolution of public choice theory in the past 20 years directed our attention to this important aspect" and (1997, p. 290) "Total welfare is further reduced, government programs increase, the budget balloons and the range of influence open to a bureaucracy expands". Mark Jackson (2005, p. 282) argues that the net welfare cost of successful rent seeking activity is remarkably underestimated. Parente and Prescott (2000, p. 145) estimate that if we remove institutional barriers, nations can produce gains 1000 or 2000 percent!
} 
Thus, in present-day democracy, the fiscal deficit provides the worst possible service to macroeconomic and fiscal policy, exacerbating rather than moderating economic cycles, functioning as a perennial source of noise in the economy, hindering the consistent and rational decisions that could be made by maximization processes both of state authorities and individuals. At the same time it serves as the means for reproducing and further reinforcing the inordinate influence of the overly large state ${ }^{33}$ [40], whose mission is transformed from promoting the public interest to satisfying the particular interests of closed coalitions and pressure groups.

Fiscal control must therefore be brought back as a last line of defence for contemporary democracy and for the individual who is its prime subject. Within such a context fiscal policy would rediscover its authentic role and its relevance to the overall logic of a prudent macroeconomic policy ${ }^{34}$ [41]. For this to be achieved there must be a revaluation of the virtues of the $19^{\text {th }}$ century Liberal State of classical fiscal tradition, where government is limited in size and effective in the quality of its action. Fiscal control can be made possible through introduction of the balanced budget, statically, but with provision for its dynamic implementation over time through permanent offsetting of deficits and surpluses depending on the rising or falling momentum of the economic cycle.

If moreover we provide modern democracy with panoply of constitutional restrictions $^{35}$ [36] [42] [43] [55] on the fiscal deficit and on public debt, and revive the principle of unanimity or near unanimity on major political collective decisions (Knut Wicksell, 1958) [44], we will have offered a secure method and a policy for contemporary rapprochement between government and public interest in a reconstituted democratic state.

\section{Constitutional Consolidation of Fiscal Stability}

In a democratic society the state must have a limited role, leaving the maximum possible decision-making space to the market ${ }^{36}$ [7]. As I have attempted to ${ }^{33}$ Specific analysis in Chapter 9, "The Threat of Leviathan", in the book by James M. Buchanan, "The Limits of Liberty. Between Anarchy and Leviathan”, The University of Chicago Press, 1974.

${ }^{34}$ Although in 2001 the US economy was not suffering a public deficit problem, W. Lee Hoskins (2001, p. 259) warned, and indeed underlined, that "Sound fiscal policy clearly sets out priorities and maps out multiyear commitments for taxes and spending... And sound fiscal policy communicates each of these objectives clearly within long-term budget constraints so that private decision making is consistent with efficient resource allocation. Key to me is a long-term budget constraint."

${ }^{35}$ This is the greatest contribution of the Public Choice School to contemporary fiscal policy: constitutionally underwritten limitation of fiscal deficits and public debt. See in this connection Geoffrey Brennan and James M. Buchanan, "Towards a Tax Constitution for Leviathan" in the Journal of Public Economics 8 (1977): 255-73, republished in “The Theory of Public Choice-II", James M. Buchanan and Robert D. Tollison (eds), The University of Michigan, 1984. For the same subject in Chapter 21, "The Constitution of Economic Policy", op. cit., James M. Buchanan, (1987) and also the article "Contractarian Political Economy and Constitutional Interpretations", American Economic Review, May 1988, pp. 135-39.

${ }^{36}$ James M. Buchanan (2005, p. 27) explicitly explains why our academic task is to get the truths of economic science through to the wider audience of ordinary people as well. "The spontaneous order of the market-this is an intellectual idea that is not naturally understood by those who have not been exposed to the teachings of economists. And economists themselves in their sometimes zeal for working out the intricacies of complex models have neglected their primary didactic purpose". 
demonstrate, on the basis of the principles of the classical approach to economics, the state must be treated as a mechanism for community action subject to rational restraints imposed by individuals in constitutive agreement between themselves so that their collaboration may take place in an organized manner, with institutions and rules, in such a way as to maximise the positive outcomes of social cooperation and minimise the problems, conflicts and improper conduct $^{37}[38]$.

In the opposite eventuality, that of blunting the rational restraints on state intervention, legislative reinforcement of state power for a more active presence in organized economic and social life, but also with entrenchment of bureaucracy in its procedural role, then the state acquires an organic relationship with individuals in the community, approaching them as inseparable elements of its own organism, composition, development and expansion, with effacement of individual rights and values as the inevitable consequence.

In this unfortunate circumstance the state evolves on the basis of its own internal organic logic ${ }^{38}[7]$, which is purely biological in character and centred on a self-feeding process which through constant incorporation into its operations of ever more resources leads to its anti-productive and illiberal gigantism ${ }^{39}$ [7].

Restoration of fiscal control and stability in the form of constitutional restrictions ${ }^{40}$ [27], with institutionalized adoption of the balanced budget in its dynamic form of implementation, in parallel with-and contingent on the evolution of-the phases of economic cycles, provides a potential for rationalization of the public sector in terms of size ${ }^{41}$ [7] [41], not granting the political system and its bureaucracy the leeway in funding for individuals in society to be exposed to the peculiar form of slavery that prevails if the state becomes a Leviathan.

\section{Conclusion}

Contemporary democracy can progress towards effective social organization when individual rights leave room for individual choices whose overall outcome forms the collective choice through the mechanism of the market in a regime of

${ }^{37}$ Mark Jackson (2005, p. 277) explains how the application of constitutional economics contributes on this strategy. "Constitutional economics proposes and pursues a strategy to solve public-policy problems, one that supplies rules designed to reduce the opportunity set that rational politicians confront."

${ }^{38}$ James M. Buchanan, (2005, p. 23), attributes the strength of the state and the high demand for a nanny state even in the $21^{\text {st }}$ century to the fear of the people to undertake their own responsibilities. "And it seems evident that many persons do not want to shoulder the final responsibility for their own actions. Many persons are, indeed, afraid to be free."

${ }^{39}$ James M. Buchanan, (2005, p. 29), “The liberal principle that persons are to be free to create taxable capacity as and if they so choose is not consistent with the socialist principle that the welfare dependency be expanded beyond plausibly acceptable fiscal limits."

${ }^{40}$ James M. Buchanan, (1993, 1), "Or, in other terms, how could the constitutional framework be reformed so that players who advance generalized interests are rewarded rather than punished."

${ }^{41} J a m e s$ M. Buchanan, (2005, p. 28), "Such an idealized capitalistic system would, at most, command collectively up to fifteen percent of national value product” and W. Lee Hoskins, (2001, p. 259), “A constitutional amendment limiting government share to something less than twenty percent over a multiyear period would provide the necessary long term focus for fiscal policy, giving it some credibility and predictability." 
freedom underwritten by a system of legal rules. In those specific and necessary issues where a collective decision is required for the proper functioning of social organization, the state can act within a framework of strict limitations imposed by individuals with high-level constitutional backing. The constitution in this case plays a decisive role in ensuring that its manner of drafting and the high principles of its elaboration place effective limitations on the state, not allowing the constitution to be used as a legislative point of departure for the further expansion of the state and the exacerbation of its public deficit and debt. On this consolidated constitutional base, an economic policy on the direction of public choice analysis can restore the fiscal stability before the sovereign debt crisis breaks out, bringing the global economy to its knees.

\section{References}

[1] Machiavelli, N. (2004) The Prince. Bedford/St. Martin's, Boston, New York.

[2] Hobbes, T. (1996) Leviathan. Cambridge University Press, Cambridge.

[3] Locke, J. (1988) Two Treatises of Government. Cambridge University Press, Cambridge. https://doi.org/10.1017/CBO9780511810268

[4] Smith, A. (1976) An Inquiry into the Nature and Causes of the Wealth of Nations. Oxford University Press, Oxford.

[5] Marx, K. (1967) Capital. International Publishers, New York.

[6] Marx, K. and Engels, F. (1952) The Manifesto of the Communist Party. In: Samuelson, P.A., Bishop, R.L. and Coleman, J.R., Eds., Readings in Economics, McGraw-Hill Book Company, New York, 395-404.

[7] Buchanan, J.M. (2005) Afraid to Be Free: Dependency as Desideratum. Public Choice, 124, 19-31. https://doi.org/10.1007/s11127-005-4743-2

[8] Kornai, J. (1993) Market Socialism Revisited. In: Bardhan, P.K. and Roemer, J.E., Eds., Market Socialism, The Current Debate, Oxford University Press, Oxford, Chapter 2, 41 .

[9] Hayek, F. (1935) The Nature and History of the Problem. In: Hayek, F.A., Ed., Collectivist Economic Planning, George Routledge \& Sons, London, 1-40.

[10] Hayek, F. (1940) Socialist Calculation: The Competitive Solution. Economica, 7, 125-149. https://doi.org/10.2307/2548692

[11] Hayek, F. (1988) The Fatal Conceit: The Errors of Socialism. University of Chicago Press, Chicago.

[12] Von Mises, L. (1935) Economic Calculations in the Socialist Commonwealth. In: Hayek, F.A., Ed., Collectivist Economic Planning, George Routledge \& Sons, London, 87-130.

[13] Von Mises, L. (1981) Socialism, Indianapolis. Liberty Fund, Carmel.

[14] Kornai, J. (1959) Overcentralization in Economic Administration. Oxford University Press, Oxford.

[15] Kornai, J. (1971) Anti-Equilibrium. North Holland, Amsterdam.

[16] Kornai, J. (1992) The Socialist System: The Political Economy of Communism. Princeton University Press, Princeton and Oxford University Press, Oxford.

[17] Boettke, P.J. (2001) Calculation and Coordination. Routledge, New York. https://doi.org/10.4324/9780203469682 
[18] Prychitko, D.L. (2002) Markets, Planning and Democracy: Essays after the Collapse of Socialism. Edward Elgar, Cheltenham. https://doi.org/10.4337/9781843767381

[19] Evangelopoulos, P. (2009) Institutional Failures of Socialism. Economic Affairs, 29, 72-77. https://doi.org/10.1111/j.1468-0270.2009.01950.x

[20] North, D.C. (1981) Structure and Change in Economic History. W.W. Norton, New York.

[21] Smith, D.B. (2006) Living with Leviathan: Public Spending Taxes and Economic Performance. Institute of Economic Affairs, London.

[22] Buchanan, J.M. and Kafoglis, M.Z. (1963) A Note on Public Choice Supply. The American Economic Review, 53, 403-414.

[23] Buchanan, J. and Tullock, G. (1962) The Calculus of Consent. Logical Foundations of Constitutional Democracy, The University of Michigan, Ann Arbor.

[24] Buchanan, J.M. and Wagner, R.E. (1977) Democracy in Deficit: The Political Legacy of Lord Keynes. Academic Press, New York.

[25] Keynes, J.M. (1973) The General Theory of Employment, Interest and Money. Macmillan Cambridge University Press, London.

[26] Buchanan, J.M. and Wagner, R.E. (1978) Fiscal Responsibility in Constitutional Democracy. Martinus Nijhoff, Leiden. https://doi.org/10.1007/978-1-4684-7125-0

[27] Buchanan, J.M. (1993) How Can Constitutions Be Designed So That Politicians Who Seek to Serve "Public Interest" Can Survive and Prosper? Constitutional Political Economy, 4, 1-6. https://doi.org/10.1007/BF02393280

[28] Smith, D.B. (2009) How Should Britain's Government Spending and Tax Burdens Be Measured? A Historic Perspective on the 2009 Budget Forecasts. Economic Affairs, 29, 37-47. https://doi.org/10.1111/j.1468-0270.2009.01945.x

[29] Evangelopoulos, P. (2009) The 1930s and the Present Day-Crises Compared. Economic Affairs, 29, 80-82. https://doi.org/10.1111/j.1468-0270.2009.01952.x

[30] Evangelopoulos, P. (2007) Towards a Synthesis of Theories of State Failure. International Review of Economics, 54, 13-34. https://doi.org/10.1007/s12232-007-0004-7

[31] Rowley, C.K. and Smith, N. (2009) Economic Contractions in the United States: A Failure of Government. The Locke Institute, Fairfax and Institute of Economic Affairs, London.

[32] Lekachman, R. (1964) Keynes' General Theory. Reports of Three Decades St. Martin's Press-MacMillan \& Co. Ltd.

[33] Chick, V. (1983) Macroeconomics after Keynes. Philip Allan Publishers.

[34] Hicks, J. (1974) The Crisis in Keynesian Economics. Basil Blackwell, Oxford.

[35] Robinson, J. (1978) Contributions to Modern Economics. Basil Blackwell, Oxford.

[36] Buchanan, J.M. (1987) Economics between Predictive Science and Moral Philosophy. Texas A\&M University Press, College Station.

[37] Pejovich, S. (1997) The Economic Foundations of Property Rights. Edward Elgar Publishing Ltd., Cheltenham.

[38] Jackson, M. (2005) Liberty and Economic Growth in Adam Smith's Possible World. Constitutional Political Economy, 16, 277-284. https://doi.org/10.1007/s10602-005-2834-1

[39] Parente, S.L. and Prescott, E.C. (2000) Barriers to Riches. The MIT Press, Cambridge.

[40] Buchanan, J.M. (1974) The Limits of Liberty between Anarchy and Leviathan. The University of Chicago Press, Chicago. 
[41] Hoskins, W.L. (2001) Economic Policy: Credible Commitments. Cato Journal, 21, 255-261.

[42] Buchanan, J.M. and Tollison, R.D. (1984) The Theory of Public Choice-II. The University of Michigan, Ann Arbor. https://doi.org/10.3998/mpub.7229

[43] Buchanan, J.M. (1988) Contractarian Political Economy and Constitutional Interpretations. American Economic Review, 78, 135-139.

[44] Wicksell, K. (1958) Finanz Theoretische Untersuchungen. In: Musgrave, R.A. and Peacock, A.T. Eds., Classics in the Theory of Public Finance, Macmillan, London, 72-118.

[45] Paul, E.F. (1987) Property Rights and Eminent Domain. Transaction Inc.

[46] von Mises, L. (2010) Human Action: A Treatise on Economics. Liberty Fund, Carmel, IN.

[47] von Mises, L. (2005) Liberalism. Liberty Fund, Carmel, IN.

[48] Hayek, F. (1976) Law, Legislation and Liberty. Routledge \& Kegan Paul, UK.

[49] Hayek, F. (1978) Studies in Philosophy, Politics and Economics. Routledge \& Kegan Paul, UK.

[50] Friedman, M. (1982) Capitalism and Freedom. The University of Chicago Press, Chicago.

[51] Buchanan, J.M. (1999) The Logical Foundations of Constitutional Liberty. Liberty Fund, Carmel.

[52] Buchanan, J.M. (2004) Collected Works of James M. Buchanan. Liberty Fund, Carmel.

[53] Coase, R.H. (1988) The Firm, the Market, and the Law. The University of Chicago Press, Chicago.

[54] Galbraith, J.K. (1973) Economics and the Public Purpose. Houghton Mifflin Co., Boston.

[55] Brennan, G. and Buchanan, J.M. (1977) Towards a Tax Constitution for Leviathan. Journal of Public Economics, 8, 255-273. 